\title{
管下端をばね支持された弾性送水管の管内脈動流による空間運動*
}

\author{
山下清 隆*1, 吉 沢 正 紹*2, 阿 形 淳*3 \\ 網 代 惊 治*3, 谷口章*3
}

\section{Non-planar Vibration of a Pipe due to a Pulsating Fluid Flow with a Spring Supported End}

\author{
Kiyotaka YAMASHITA*4, Masatsugu YOSHIZAWA, Jun AGATA, \\ Junji AJIRO and Akira TANIGUCHI \\ ${ }^{* 4}$ Fuculty of Engineering, Fukui University of Technology, \\ 3-6-1 Gakuen, Fukui-shi, Fukui, 910-8505 Japan
}

\begin{abstract}
Spatial behavior of a pipe conveying fluid is examined theoretically and experimentally under the condition that the pipe has an asymmetric spring supported end. The planar motion, nonplanar motion and beating, chaotic phenomena of the pipe vibration exist depending on the frequency of the pulsating flow velocity and the perturbed parameter of the spring coefficient. Furthermore the experiments were conducted with the silicon rubber pipe conveying water. The spatial displacements of the pipe were measured by the image processing system, which was based on the images from two $\mathrm{CCD}$ cameras. The typical features of the pipe vibrations, as predicted by the theory, were confirmed qualitatively.
\end{abstract}

Key Words: Parametric Excitation, Self-Excited Vibration, Nonlinear Vibration, Vibration of Continuous System, Flexible Pipe

\section{1.は じめに}

内部流による片持ち弾性送水管の横振動は，管内定 常流速がある臨界值に近づくと特定のモードの減衰比 が非常に小さくなり, 流速の増加に伴いやがて負とな る特徵がある(1). そのためこの臨界流速近傍において, 管内流速の定常成分による自励的横振動および管内流 速の脈動成分による係数励振について数多くの研究が 報告されてきた(1)(2).

これらの研究の中で管内流速の定常成分が臨界流速 を僅かに越えなおかつ管内流速が微小な脈動成分を有 する場合, すなわち自励的横振動および係数励振現象 の双方が発生する可能性がある場合について不安定振 動発生後の管の挙動を調べたものがある ${ }^{(3)(4)}$. しかし ながらこれらの研究は，管の運動を平面内に拘束した 場合であり，管の空間的挙動については議論がなされ ていない.

著者らは一連の研究で, 管下端に取り付けられた付

* 原稿受付 2006 年 8 月 4 日

*1 正員, 福井工業大学工学部 (焉 910-8505 福井市学園 3-6-1).

*2 正員, 慶應義塾大学理工学部(画 223-8522 横浜市港北区日 吉 3-14-1).

*3 慶應義塾大学理工学部.

E-mail : yamashita@fukui-ut.ac.jp
加質量やばねが管内定常流速による自励的横振動に与 える影響を調べ，管が平面運動および空間円運動をす ることを指摘してきた ${ }^{(5)(6)}$. また管下端のばね支持の 僅かな非対称性により管はいくつかのパターンの空間 運動をする事を報告してきた ${ }^{(6)(7)}$

前報と同様に ${ }^{(6)(7)}$ ，鉛直に吊り下げられ管上端を固 定支持された弾性送水管の横振動を取り上げる. 本報 では，管内流速に微小な脈動成分が存在する場合を取 り上げ，その振動数が管内定常流速により不安定化す るモードの固有振動数の 2 倍近傍の場合を考える.す なわち管内定常流速による自励振動と管内流速の脈動 成分による係数励振の相互的な影響を議論する。

そこで第一歩として管内流速の定常成分による管の 自励的横振動が面内振動として現れる場合について, 管の横振動に与える管内流速の脈動成分の影響を調べ る．また空間的挙動を議論する上で，管下端のばね支 持が管の横振動に与える影響も議論する.

次章以降では最初に, 非自己随伴形偏微分方程式で 記述される管横变位の支配方程式から求めた管の複素 振幅方程式を用いて，管の空間運動に与えるばね支持 の影響を理論的に調べる. 


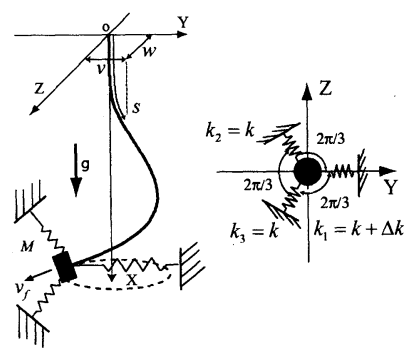

Fig. 1 Analytical model

次に前報 ${ }^{(6)}(7)$ と同様な計測系により，測定される水 平面内二方向での管横変位の時刻歴とこれに対応する 理論解析結果との比較・検討を行なう.

\section{2. 解析モデルと運動方程式}

2.1 解析モデル 前報 ${ }^{(6)}$ (7) と同様な図 1 に示さ れる, 上端を固定され， $X-Y-Z$ 空間で運動する弾 性送水管を考える. 付加質量 $M$ が取り付けられた管 の下端 $(s=l)$ は, 管軸に対して対称に配置されたばね で三点支持され，三本のばねの自然長はすべて $L$, そ のばね定数は，それぞれ， $k_{1}=k+\Delta k, k_{2}=k_{3}=k$ で ある。

2.2 弾性送水管の運動方程式と境界条件管の 流路断面積 $S$ は一定で, 管全長 $l$ は管径に比べて十分 長く, 管下端から密度 $\rho$ の非圧縮性流体が放出されて いる．管内の流れは管軸 $s$ に沿った一次元定常流れと みなし，管に相対的な流速 $v_{f}$ は脈動成分を有し以下 のようにあらわされる.

$$
v_{f}=v_{s}+\Delta v=v_{s}(1+\varepsilon \cos N t)
$$

単位長さ当りの質量 $m$ の弾性送水管を, 長さの変化 しない曲げ剛性 $E I$ の弾性はりとみなし，管は中心軸 に関してねじれないと仮定する. 前報 ${ }^{(7)} と$ 同様に管の $Y$ 方向の運動を支配する方程式および境界条件は，横 変位 $v, w$ の三乗までを考慮して以下の無次元形式であ らわされる。

$$
\begin{aligned}
& \ddot{v}+c \dot{v}+\delta \dot{v}^{\prime \prime \prime}+2 \sqrt{\beta} v \dot{v}^{\prime}+V^{2} v^{\prime \prime} \\
& -\gamma\left[(\alpha+1-s) v^{\prime}\right]^{\prime}+v^{\prime \prime \prime \prime}+(1-s) \sqrt{\beta} \dot{v} v^{\prime \prime} \\
& =-v^{\prime \prime} \int_{s}^{1}\left[-\frac{1}{2} \frac{\partial^{2}}{\partial t^{2}}\left(\int_{0}^{s} v^{\prime 2}+w^{\prime 2}\right) d s+v^{\prime} \ddot{v}\right. \\
& \left.+w^{\prime} \ddot{w}\right] d s-\frac{1}{2} v^{\prime} \frac{\partial^{2}}{\partial t^{2}} \int_{0}^{s}\left(v^{\prime 2}+w^{\prime 2}\right) d s+\frac{1}{2} v^{\prime 2} \ddot{v} \\
& +\frac{1}{2} \ddot{w}\left[v^{\prime} w^{\prime}-\int_{0}^{s}\left(v^{\prime} w^{\prime \prime}-v^{\prime \prime} w^{\prime}\right)\right] d s \\
& -\alpha v^{\prime \prime}\left[-\frac{1}{2} \frac{\partial^{2}}{\partial t^{2}} \int_{0}^{1}\left(v^{\prime 2}+w^{\prime 2}\right) d s+v_{1}^{\prime} \ddot{v}_{1}+w_{1}^{\prime} \ddot{w}_{1}\right]
\end{aligned}
$$

$$
\begin{aligned}
& +\frac{1}{2} \alpha \gamma\left[v^{\prime}\left(v^{\prime} v^{\prime \prime}+w^{\prime} w^{\prime \prime}\right)+w^{\prime \prime} \int_{0}^{s}\left(v^{\prime} w^{\prime \prime}-v^{\prime \prime} w^{\prime}\right) d s\right. \\
& \left.-v^{\prime \prime}\left(v_{1}^{\prime 2}+w_{1}^{\prime 2}\right)\right]-\frac{1}{2} \gamma^{\prime \prime} \int_{s}^{1}\left(v^{\prime 2}+w^{\prime 2}\right) d s \\
& +\frac{1}{2}(1-s) \gamma\left[v^{\prime}\left(v^{\prime} v^{\prime \prime}+w^{\prime} w^{\prime \prime}\right)\right. \\
& \left.+w^{\prime \prime} \int_{0}^{s}\left(v^{\prime} w^{\prime \prime}-v^{\prime \prime} w^{\prime}\right) d s\right]-\frac{1}{2} \gamma\left[w ^ { \prime } \int _ { 0 } ^ { s } \left(v^{\prime} w^{\prime \prime}\right.\right. \\
& \left.\left.-v^{\prime \prime} w^{\prime}\right) d s\right]+v^{\prime \prime} \int_{s}^{1}\left(v^{\prime \prime} v^{\prime \prime \prime}+w^{\prime \prime} w^{\prime \prime \prime}\right) d s \\
& -\frac{1}{2}\left[v^{\prime}\left(v^{\prime} v^{\prime \prime}+w^{\prime} w^{\prime \prime}\right)+w^{\prime \prime} \int_{0}^{s}\left(v^{\prime} w^{\prime \prime}-v^{\prime \prime} w^{\prime}\right) d s\right]^{\prime \prime} \\
& -\frac{1}{2} V_{s}^{2}\left[v^{\prime}\left(v^{\prime} v^{\prime \prime}+w^{\prime} w^{\prime \prime}\right)+w^{\prime \prime} \int_{0}^{s}\left(v^{\prime} w^{\prime \prime}-v^{\prime \prime} w^{\prime}\right) d s\right] \\
& -\sqrt{\beta} V_{s}\left[v^{\prime}\left(v^{\prime} \dot{v}^{\prime}+w^{\prime} \dot{w}^{\prime}\right)+\dot{w}^{\prime} \int_{0}^{s}\left(v^{\prime} w^{\prime \prime}-v^{\prime \prime} w^{\prime}\right) d s\right] \\
& -\frac{3}{2} \kappa v_{1} v_{1}^{\prime} v^{\prime \prime}-\frac{3}{2} \kappa w_{1} w_{1}^{\prime} v^{\prime \prime} \\
& s=0: \quad v=v^{\prime}=0 \\
& s=1: \quad v^{\prime \prime}+\delta \dot{v}^{\prime \prime}=0 \\
& v^{\prime \prime \prime}-\alpha \gamma v^{\prime}-\alpha \ddot{v}-c \dot{v}+\delta \dot{v}^{\prime \prime \prime}+F_{v}= \\
& \frac{1}{2} \alpha\left[v^{\prime} \frac{\partial^{2}}{\partial t^{2}} \int_{0}^{s}\left(v^{\prime 2}+w^{\prime 2}\right) d s-\ddot{v} v^{\prime 2}\right. \\
& \left.-\ddot{w} v^{\prime} w^{\prime}-\ddot{w} \int_{0}^{s}\left(v^{\prime} w^{\prime \prime}-v^{\prime \prime} w^{\prime}\right) d s\right]-\frac{3}{4} \kappa v v^{\prime 2} \\
& +\frac{3}{4} \kappa w\left[\int_{0}^{s}\left(v^{\prime} w^{\prime \prime}-v^{\prime \prime} w^{\prime}\right) d s-w^{\prime} v^{\prime}\right] \\
& -\frac{1}{2}\left[v^{\prime}\left(v^{\prime} v^{\prime \prime}+w^{\prime} w^{\prime \prime}\right)+w^{\prime \prime} \int_{0}^{s}\left(v^{\prime} w^{\prime \prime}-v^{\prime \prime} w^{\prime}\right) d s\right]^{\prime}(3)
\end{aligned}
$$

ただし

$$
\begin{aligned}
F_{\nu}= & \kappa\left[-\left(3 / 2+\varepsilon_{\kappa}\right) v-9 v^{2} / 8 l_{1}+9 w^{2} / 8 l_{1}\right. \\
& \left.+3 v^{3} / 16 l_{1}^{2}+3 v w^{2} / 16 l_{1}^{2}\right]
\end{aligned}
$$

である。

式(2)〜(4)およびこれ以降は, 簡単のため無次元量を あらわす記号＊は省略する. 添え字 1 が付加されている 記号は，管下端 $(s=1)$ での值を意味する. また $(\cdot),(\cdot)^{\prime}$ はそれぞれ時間 $t$, 空間 $s$ にいての微分を意味する. な お式 (2)の線形項に含まれる流体力は Païdoussis, M.P. らの研究 ${ }^{(1)}$ 参考に, 流体のコリオリカ $2 \sqrt{\beta} V \dot{v}^{\prime}$, 遠 心力 $V^{2} v^{\prime \prime}$ および非定常流体力 $(1-s) \sqrt{\beta} \dot{V} v^{\prime \prime}$ が考慮 され，流体の乱流などの効果は考慮していない.

さらに $w$ についての支配方程式および境界条件は， 式(2),(3)において $v$ と $w$ を入れ替え, $F_{v}$ を

$$
\begin{aligned}
F_{w}= & \kappa\left[-3 w / 2-9 v w / 4 l_{1}+3 w^{3} / 16 l_{1}^{2}\right. \\
& \left.+3 w v^{2} / 16 l_{1}^{2}\right]
\end{aligned}
$$


と入れ替えたものとなる.

以上より管の空間運動は, 式 (2)〜 (4) と, 同方程式 系で未知数 $v$ と $w$ を入れ替えた方程式系とであらわ される.このとき未知数 $v, w$ は, 独立変数 $s, t$ と 11 個 の無次元パラメータ，つまり管に相対的な管軸方向の 無次元管内流速 $V=v_{f} / \sqrt{E I /\left(\rho S l^{2}\right)}$, 管および管内流 体の全質量に対する付加質量の比 $\alpha=M /(m+\rho S) l$, 管内流体の無次元質量 $\beta=\rho S /(m+\rho S)$, 重力と弾 性力の比 $\gamma=(m+\rho S) g l^{3} / E I$, 無次元外部減衰係数 $c=C l^{2} / \sqrt{E I(m+\rho S)}$, 管の無次元内部減衰係数 $\delta=$ $E^{*} /\left[l^{2} E \sqrt{E I /(m+\rho S)}\right]$,管下端を弾性支持するばねの 無次元ばね定数 $\kappa=k l^{3} / E I$, 管下端のばね支持の非対 称性 $\varepsilon_{\kappa}=\Delta k / k$, 管全長に対する管下端の支持ばねの長 さ $l_{1}=L / l$, 管内流速の脈動成分の大きさ $\varepsilon=|\Delta v| / v_{s}$ および脈動流成分の振動数 $v=N \sqrt{(m+\rho S) l^{4} / E I}$, で あらわされる. また便宜的に無次元定常流速を $V_{s}$ と 表記する.

2.3 運動方程式と境界条件のベクトル表記 式 (2)〜(4) および $w$ に関する同方程式系を, ベクトル 表記に書き改める. すなわち $\boldsymbol{v}_{v}={ }^{t}(v \partial v / \partial t), \boldsymbol{v}_{w}={ }^{t}$ $(w \partial w / \partial t)$ とおくと, $v_{j}$ の支配方程式は以下のよう になる.

$$
\frac{\partial v_{j}}{\partial t}=\boldsymbol{L} \boldsymbol{v}_{j}+\boldsymbol{N}_{j}
$$

式 (6) およびこれ以降, 添え字 $j$ は, $j=v, w$ を意味す る. また $\boldsymbol{L}_{21}=-(\cdot)^{\prime \prime \prime \prime \prime}+\gamma\left[(\alpha+1-s)(\cdot)^{\prime}\right]^{\prime}-V_{s}^{2}(\cdot)^{\prime \prime}$ およ び $\boldsymbol{L}_{22}=-2 \sqrt{\beta} V_{s}(\cdot)^{\prime}-\delta(\cdot)^{\prime \prime \prime \prime}-c(\cdot)$ として

$$
\boldsymbol{L}=\left(\begin{array}{cc}
0 & 1 \\
\boldsymbol{L}_{21} & \boldsymbol{L}_{22}
\end{array}\right), \boldsymbol{N}_{j}=\left(\begin{array}{c}
0 \\
n_{j}
\end{array}\right)
$$

である.ここで $n_{j}$ は, 式(2) で示した非線形項とそれと 同程度の大きさを持つと考えた管内脈動流に起因する 励振項 $-\left(V^{2}-V_{s}^{2}\right) v^{\prime \prime}-2 \sqrt{\beta}\left(V-V_{s}\right) v^{\prime}-(1-s) \sqrt{\beta} \dot{V} v^{\prime \prime}$ が含まれている.

境界条件は

$$
s=0: B_{1} v_{j}=0, \quad s=1: B_{2} \dot{v}_{j}=B_{3} v_{j}-N_{b}
$$

である. ただし $\boldsymbol{L}_{b}=(\cdot)^{\prime \prime \prime}-\alpha \gamma(\cdot)^{\prime}-3 \kappa / 2$ として

$$
\begin{aligned}
\boldsymbol{B}_{1} & =\left(\begin{array}{cc}
1 & 0 \\
(\cdot)^{\prime} & 0
\end{array}\right), \quad \boldsymbol{B}_{2}=\left(\begin{array}{ll}
0 & 0 \\
0 & \alpha
\end{array}\right), \quad \boldsymbol{N}_{b}=\left(\begin{array}{c}
0 \\
b_{j}
\end{array}\right) \\
\boldsymbol{B}_{3} & =\left(\begin{array}{cc}
(\cdot)^{\prime \prime} & \delta(\cdot)^{\prime \prime} \\
\boldsymbol{L}_{b}-\kappa \varepsilon_{\kappa} \delta_{j v} & \delta(\cdot)^{\prime \prime \prime}-c(\cdot)
\end{array}\right)
\end{aligned}
$$

である. $\delta_{j v}$ は, ディラックのデルタ記号で, $\delta_{v v}=1$ および $\delta_{w v}=0$ を意味する.ここで $b_{j}$ は横変位 $v, w$ の 三乗で記述される非線形項である.

\section{3. 管の自由振動に与える定常流速の影響}

管横変位の自明な平衡状態の安定性に与える定 常流速 $V_{s}$ の影響を調べる.つまり $\boldsymbol{q}_{j}$ を $\boldsymbol{q}_{j}(s)={ }^{t}$ $\left(\Phi_{1 j}(s) \quad \Phi_{2 j}(s)\right)$ としたのち, $\boldsymbol{v}_{j}=\boldsymbol{q}_{j} e^{\lambda_{j} t}$ とし, 式 (6),(8) に代入して固有値問題に帰着させた．非自明 な固有関数ベクトル $\boldsymbol{q}_{j}$ が存在する条件から, 複素固 有值 $\lambda_{j}=i\left(\omega_{j r}+i \omega_{j i}\right)$ を求めた. ここで $\omega_{j r}$ および $\omega_{j i}$ は, 各固有振動モードにおける固有振動数, 減衰比に 対応する.

前報 ${ }^{(7)}$ と同様に，管内定常流速の増加により管の横 振動の二次モード成分のみが不安定化する場合を取り 上げる，以降，二次の固有振動モードを単に二次モー ドと呼ぶことにし， $\omega_{j r}$ と $\omega_{j i}$ は二次モードに関する ものとする.

なお次章以降計算に用いる式(6),(8) に含まれる無次 元パラメータの值が $V_{s}=5.95, \alpha=0.21, \beta=0.24, \gamma=$ $20.6, c=0.051, \delta=0.001, \kappa=5.0$ および $\varepsilon_{\kappa}=0.24$ の場合, $\omega_{v r}=16.12, \omega_{w r}=16.05, \omega_{v i}=-0.06$ および $\omega_{w i}=-0.14$ であった. $\varepsilon_{\kappa}=0.0$ の場合, $\lambda_{v}$ は $\lambda_{w}$ と一 致する.なお計算に用いた無次元パラメータの值は, 第 5 章の実験值に対応している.

\section{4. 管の横振動に与える管内脈動流の影響}

本節では, 管内脈動流成分の振動数 $v$ は, 二次モ一 ドの固有振動数 $\omega_{r}$ の 2 倍近傍, つまり管の横振動の 二次モードが保数励振 (主共振) される場合を想定し て, 離調パラメータ $\sigma$ を用いて

$$
v=2 \omega_{w r}(1+\varepsilon \sigma)
$$

と表わす、ここで, $\varepsilon$ は 1 に比べて十分小さな量である. 本研究の対象としている管の横振動は, $\left|\omega_{w i}\right|$ が $\omega_{w r}$ に比べて十分小さく, $\varepsilon<<1$ であることより，二次の 固有振動数成分のみを議論する.

4.1 振幅方程式の誘導本節では, 空間運動を 含む管の横振動の複素振幅方程式を, 励振される二次 モードの成分について導出する. 弾性送水管の運動方 程式 (6) と境界条件 (8) は, 非自己随伴形偏微分方程 式系となっているため, 固有関数がお互いに直交して いない，そのため前報 (7) と同様に，随伴関数べクトル $\boldsymbol{q}_{j}^{*}$ を用いたリャプノフ・シュミットの方法により, 複 素振幅方程式を誘導した.

$\boldsymbol{v}_{j}$ を二次モードの張る固有空間とその補空間との成 分に分けて考え，以下のように記述する.

$$
\begin{aligned}
& \boldsymbol{v}_{v}=A(t) \boldsymbol{q}_{v}(s)+\boldsymbol{y}_{v}+c . c . \\
& \boldsymbol{v}_{w}=B(t) \boldsymbol{q}_{w}(s)+\boldsymbol{y}_{w}+c . c .
\end{aligned}
$$


ここで $\boldsymbol{y}_{j}$ は二次モードの補空間の要素である.ま た c.c.は，右辺第一項および第二項の共役複素数をあ らわしている。

式 (6)に射影子 $\boldsymbol{P}_{j}$ を作用させ, 二次モードの張る固 有空間に射影した。 なお射影子 $\boldsymbol{P}_{j}$ は $\boldsymbol{P}_{j} \boldsymbol{x}=<\boldsymbol{x}, \boldsymbol{q}_{j}^{*}>\boldsymbol{q}_{j}$ で与えられる.

以上より次の複素振幅方程式が得られる.

$$
\begin{aligned}
\dot{A} & =\lambda_{v} A+\xi_{1}\left(A^{2}+B^{2}+2|A|^{2}+2|B|^{2}\right) \\
& +\left(\xi_{2} A^{2}+\xi_{3} B^{2}+\xi_{4}|A|^{2}+\xi_{5}|B|^{2}\right) A+\xi_{6} B^{2} \bar{A} \\
& +\varepsilon \xi_{7} \bar{A} e^{i v t}+\varepsilon \xi_{7} A e^{i v t} \\
\dot{B} & =\lambda_{w} B+2 \xi_{1}(A B+\bar{A} B+A \bar{B}) \\
& +\left(\xi_{2} B^{2}+\xi_{3} A^{2}+\xi_{4}|B|^{2}+\xi_{5}|A|^{2}\right) B+\xi_{6} A^{2} \bar{B} \\
& +\varepsilon \xi_{7} \bar{B} e^{i v t}+\varepsilon \xi_{7} B e^{i v t}
\end{aligned}
$$

ここで右辺各項の係数 $\xi_{j}=\xi_{j r}+i \xi_{j i},(j=1,2, \cdot \cdot, 6)$ は, 2.2 節で定義された無次元パラメータ $V_{s}, \alpha, \beta$ $, \gamma, c, \delta, \kappa, l_{1}$ によって決まる複素定数であり, $\xi_{4}=\xi_{5}+\xi_{6}$ の関係がある. なお $\xi_{1}$ は, 境界条件式 (4) および式 (5) に由来する 2 乗の非線形項の係数である.

式(12)において， $\xi_{4}$ が係数である項は形式的に書 けば式 (2) および式 (3) の $v^{3}$ の非線形項に由来する. 同様に $\xi_{5}, \xi_{6}$ および $\xi_{7}$ が係数となっている項はそれぞ れ, $v w^{2}$ の非線形項および管内脈動流に起因する励振 項に由来する。

複素振幅 $A, B$ を $C e^{i v t / 2}, D e^{i v t / 2}$ としたのち, 式(12) および式(13)に代入して実部，虚部に分離した，そし て時間と共に解が緩やかに変化する椂子を調べるため, $4 \pi / v$ で平均化を行なった。 その結果, 式 (12)および 式(13)において, 以下の振幅 $a, b$ と位相 $\phi$ および $\psi$ の 方程式が誘導された. ここで $C=a e^{i \phi} / 2, D=b e^{i \psi} / 2$ の関係がある。

$$
\begin{aligned}
\dot{a}= & \left(-\omega_{v i}+\frac{1}{4} \xi_{4 r} a^{2}+\frac{1}{4} \xi_{5 r} b^{2}\right. \\
& \left.+\varepsilon \xi_{7 r} \cos 2 \phi+\varepsilon \xi_{7 i} \sin 2 \phi\right) a \\
& +\frac{b^{2}}{4}\left[\xi_{6 r} \cos 2(\psi-\phi)-\xi_{6 i} \sin 2(\psi-\phi)\right] a \\
a \dot{\phi} & =\left(-\omega_{w r} \varepsilon \sigma+\frac{1}{4} \xi_{4 i} a^{2}+\frac{1}{4} \xi_{5 i} b^{2}\right. \\
& \left.+\varepsilon \xi_{7 i} \cos 2 \phi-\varepsilon \xi_{7 r} \sin 2 \phi\right) a \\
& +\frac{b^{2}}{4}\left[\xi_{6 r} \sin 2(\psi-\phi)+\xi_{6 i} \cos 2(\psi-\phi)\right] a \\
\dot{b}= & \left(-\omega_{w i}+\frac{1}{4} \xi_{4 r} b^{2}+\frac{1}{4} \xi_{5 r} a^{2}\right. \\
& \left.+\varepsilon \xi_{7 r} \cos 2 \psi+\varepsilon \xi_{7 i} \sin 2 \psi\right) b \\
& +\frac{a^{2}}{4}\left[\xi_{6 r} \cos 2(\phi-\psi)-\xi_{6 i} \sin 2(\phi-\psi)\right] b \\
b \dot{\psi} & =\left(-\omega_{w r} \varepsilon \sigma+\frac{1}{4} \xi_{4 i} b^{2}+\frac{1}{4} \xi_{5 i} a^{2}\right.
\end{aligned}
$$

$$
\begin{aligned}
& \left.+\varepsilon \xi_{7 i} \cos 2 \psi-\varepsilon \xi_{7 r} \sin 2 \psi\right) b \\
& +\frac{a^{2}}{4}\left[\xi_{6 r} \sin 2(\phi-\psi)+\xi_{6 i} \cos 2(\phi-\psi)\right] b
\end{aligned}
$$

弾性送水管の横変位 $v, w$ は， $a, b, \phi, \psi$ を用いて以下 のようになる。

$$
\begin{aligned}
& v=a \sqrt{\Phi_{v r}^{2}+\Phi_{v i}^{2}} \cos \left[\frac{v}{2} t+\phi+\theta_{v}(s)\right] \\
& w=b \sqrt{\Phi_{w r}^{2}+\Phi_{w i}^{2}} \cos \left[\frac{v}{2} t+\psi+\theta_{w}(s)\right] \\
& \text { ここで } \Phi_{j 1}(s)=\Phi_{j r}+i \Phi_{j i}, \quad \theta_{j}(s)=\tan ^{-1}\left(\Phi_{j i} / \Phi_{j r}\right), \\
& (j=v, w) \text { である. }
\end{aligned}
$$

4.2 数値計算例 本研究で取り上げる管内脈動 流の振動数領域を明確にするために図 2 に減衰係数 $\omega_{w i}=0$ の場合について, 管内脈動流による係数励振 現象の線形安定性の結果を示す. $\varepsilon=0.09$ において, 励振領域は $|\varepsilon \sigma|<2.4 \times 10^{-2}$ である.

4.2.1 管下端のばね支持が対称な場合＼cjkstart式 (14) の左辺の時間変動項をゼロとして, 管の横振動の定常 振幅 $a_{s}, b_{s}$, 位相差 $\phi_{s}, \psi_{s}$ および゙その安定性を求めた. $a_{s}=b_{s}$ として求めた管の横振動の周波数応答は図 3 のようになる.同図において，実線および破線は，それ ぞれ安定および不安定な解を意味する.また図中の一点 鎖線は管内流速に脈動成分が存在しない場合 $(\varepsilon=0)$ に 発生する管の自励振動の振動振幅 $a_{s}=b_{s}=\sqrt{2 \omega_{w r} / \xi_{4 r}}$ を意味する. $\varepsilon \sigma \sim 0.0$ すなわち管内脈動流の振動数 $v$ が二次の固有振動数 $\omega_{w r}$ の二倍近傍において，定常な 横振動が発生している．その際の管の振動数は， $v / 2$ であり管の自励的横振動は管の横変位の係数励振現象 に引き込まれており，その振動振幅は一点鎖線で示し た定常流による自励振動の振動振幅よりも大きい.

図 4 に $\varepsilon \sigma=0.0$ の場合の管の運動する様子 $(s=0.75)$ を示す。管が平面運動を行なう面は, 初期条件に依存 し決定される.

図 5 に図 3 で安定な定常解が存在しない領域の管の 挙動ついて, 式(14) を数值積分して求めた管横変位の 時刻歷とその周波数分析結果および管の挙動を示す. 管の横振動は，うなりを伴いある平面内において発生 している. 先ほどと同様, 管の振動する平面は初期条 件に依存して決定される．また $v$ が $2 \omega_{r}$ の近傍より遠 ざかると, 図 5 の横変位の時刻歴に示すような振動振 幅のうなりは小さくなり, 図 3 の一点鎖線で示す自励 振動の振動振幅に近づいた。

管下端のばね支持が対称な場合には，管はある平面 内で運動し空間運動は発生しなかった。また管内脈動 流に起因した係数励振現象に引き込まれたり,うなり を伴う運動をする事などは，管の運動を平面内に拘束 


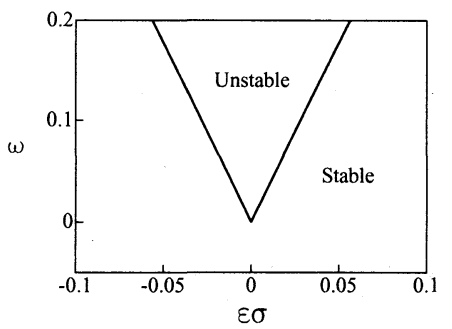

Fig. 2 Neutral Curve of the Parametric Resonance of the Pipe Vibration $\left(V_{s}=5.77, \omega_{w i}=0, \varepsilon_{\kappa}=0\right)$

して議論した Bajaj,A.K. や Semler,C. らの結果 ${ }^{(3)(4)}$ と 同様である.

4.2.2 管下端のばね支持が非対称な場合 本節 では，管下端のばね支持が非対称な場合 $\left(\varepsilon_{\kappa}=0.024\right)$ について，管の空間的挙動について調べる.

(a) 振幅方程式の定常解 図 $6 に \varepsilon_{\kappa}=0.024$ の場合 について, $a_{s}, b_{s}, \psi_{s}$ の周波数応答を示す. 図 6(a) に示 した線は，線の重なりを防ぐため鉛直方向に平行移動 させてあるが，いずれも $a_{s}=0$ を意味する. 前節の 図 5 と同様に $\varepsilon \sigma \sim 0$ において, 管の自励的横振動は 係数励振現象に引き込まれ安定な定常解が発生してい る. なおその際，管は下端支持剛性の小さい $X-Z$ 面 内で運動する.

(b) 振幅方程式の非定常解 図 6 において, 安定な 定常解が存在しない領域での管の挙動を調べるため式 (14) を数值積分した. 図 7 に, そのうちの典型的なパ ターンとして $\varepsilon \sigma=0.025,0.03,0.032,0.04$ の場合につ いて, $b$ の時刻歴および $q_{1}=b \cos \psi, q_{2}=b \sin \psi$ で与 えられる $q_{1}-q_{2}$ 平面での軌跡を示す. ここで $q_{1}, q_{2}$ は, 複素振幅 $D$ のデカルト座標系による表現に相当する. 同図 (a) (d) より, $b$ は一定值に収束せず管の横振動 の二次の固有周期 $2 \pi / \omega_{w r}$ に比べ時間的に緩やかに変 動している. 同図 (a),(c) および (d) の $q_{1}-q_{2}$ 平面で 示した軌跡は, 閉曲線を描いており, 同時に示した時 刻歴より $b$ は周期的に変動している。一方，同図 (b) では軌跡は限られた領域内に雲状に分布する特徴を示 している.

図 8 に $\varepsilon=0.025,0.03,0.032,0.04$ の場合について, $v, w$ の時刻歴およびその周波数分析結果を示す. 同図 (a),(c) の周波数分析の結果では主要な振動数成分は等 間隔に並び，その周波数の中間に小さな成分が櫛状に 派生している. なお同図 (c) の $w$ の最も支配的な振動 数成分は, 管内脈動流の影響がない場合 $(\varepsilon=0)$ に発 生する管の自励振動の振動数に相当している.

図 8(b) では，周波数は管の二次の固有振動数付近

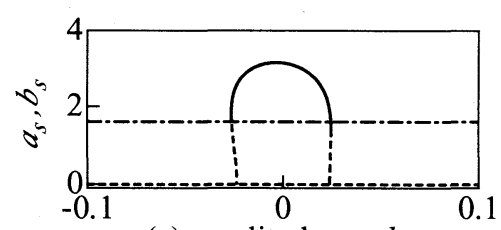

(a) amplitudes $a_{\mathrm{s}}, b_{\mathrm{s}}$

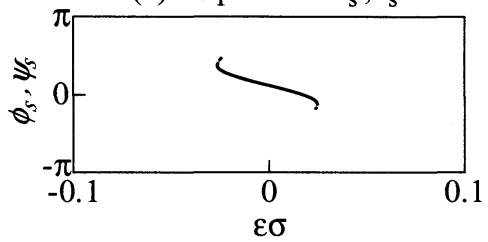

(b) phases $\phi_{\mathrm{s}}, \psi_{\mathrm{s}}$

Fig. 3 Frequency Response Curves $\left(\varepsilon=0.09, \varepsilon_{\kappa}=0\right)$

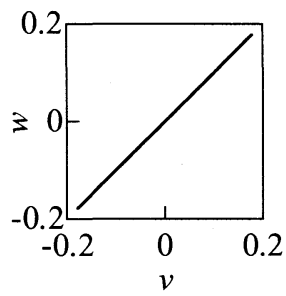

Fig. 4 Pipe motion in Y-Z plane $(\varepsilon \sigma=0.0)$
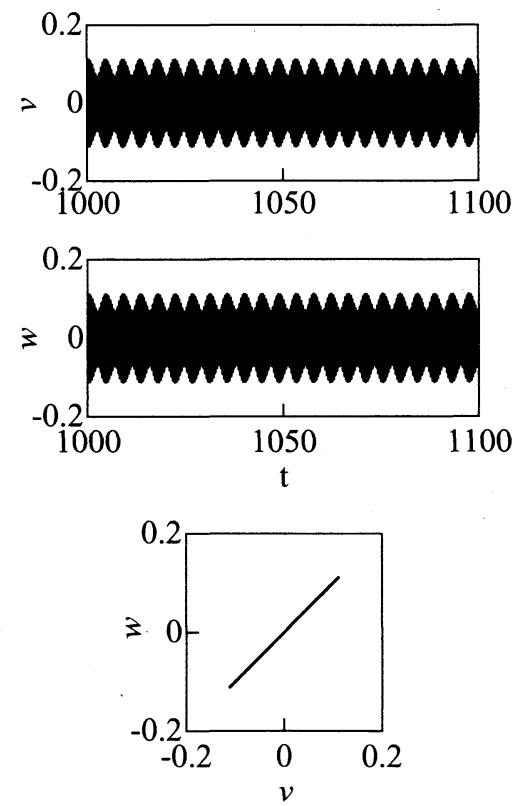

Fig. 5 Time histories of the pipe vibration and its motion in Y-Z plane $(\varepsilon \sigma=0.05)$ 


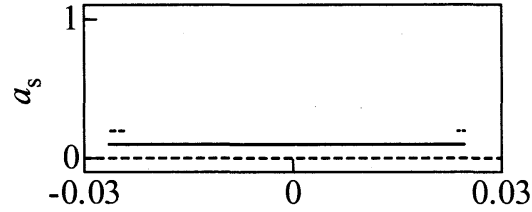

(a) amplitude $a_{\mathrm{s}}$

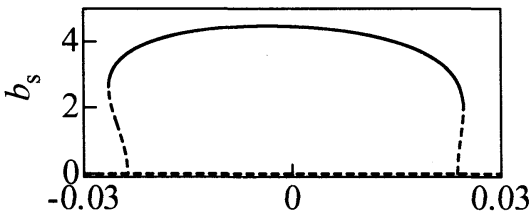

(b) amplitude $b_{\mathrm{s}}$

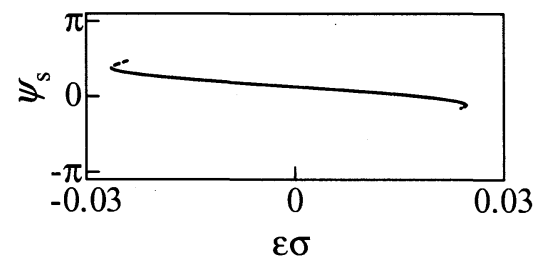

(c) phase $\psi_{\mathrm{s}}$

Fig. 6 Frequency Response Curves $\left(\varepsilon=0.09, \varepsilon_{\kappa}=\right.$ 0.024)
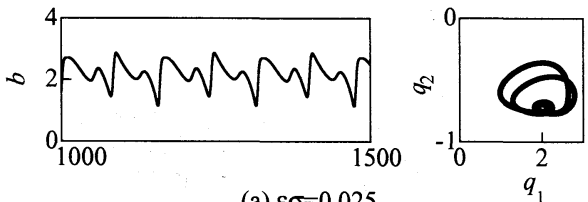

(a) $\varepsilon \sigma=0.025$

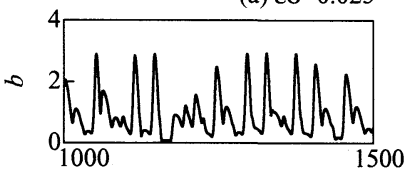

(b) $\varepsilon \sigma=0.030$
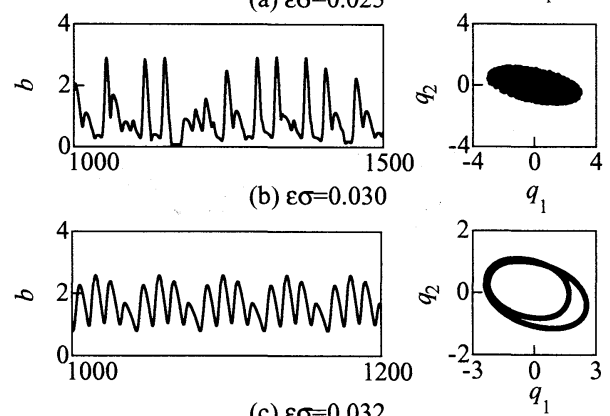

(c) $\varepsilon \sigma=0.032$

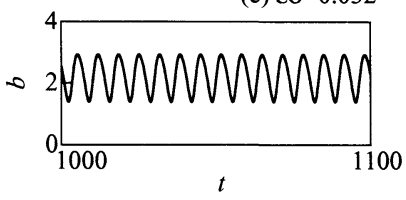

(d) $\varepsilon \sigma=0.040$

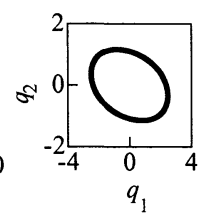

Fig. 7 Time histories of $b$ and their trajectories in the $q_{1}-q_{2}$ plane $\left(\varepsilon_{\kappa}=0.024\right)$
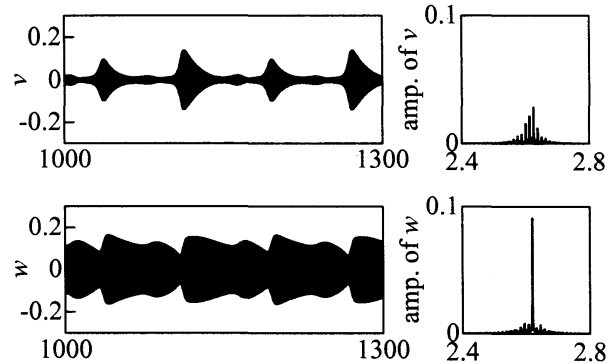

(a) $\varepsilon \sigma=0.025$
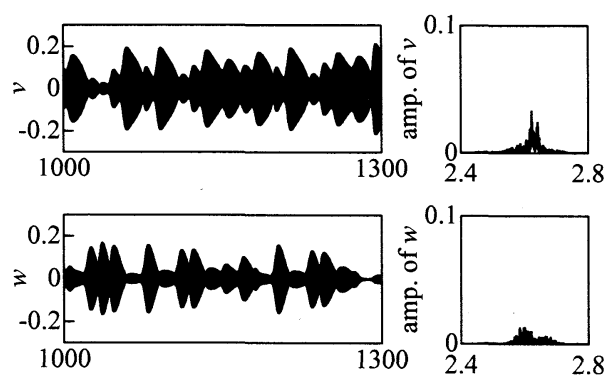

(b) $\varepsilon \sigma=0.030$
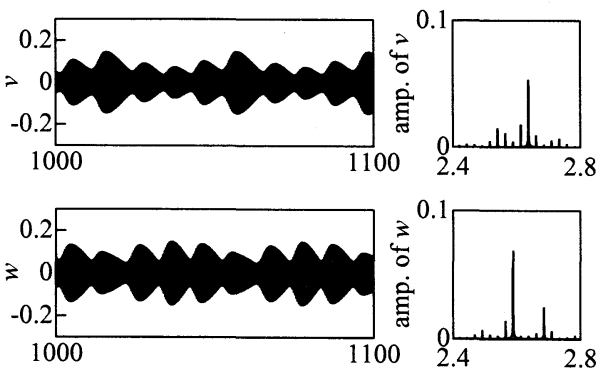

(c) $\varepsilon \sigma=0.032$
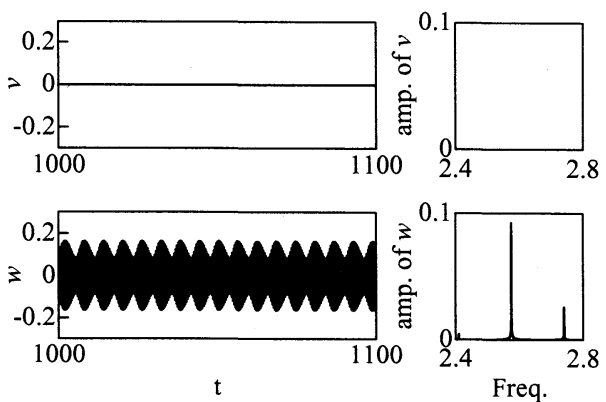

(d) $\varepsilon \sigma=0.040$

Fig. 8 Time histories of $v$ and $w\left(\varepsilon_{\kappa}=0.024\right)$

で，ある程度の幅を持って存在している．また時刻歷 にも周期性は認められない，同図 (d) では, 管の横振 動は下端支持剛性の小さな $X-Z$ 面内で発生する。下 端ばね支持が対称な場合と同様に, $v$ が $2 \omega_{r}$ から離れ 


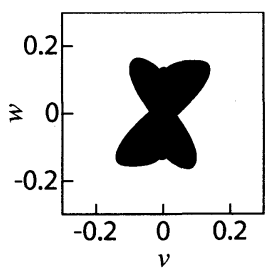

(a) $\varepsilon \sigma=0.025$

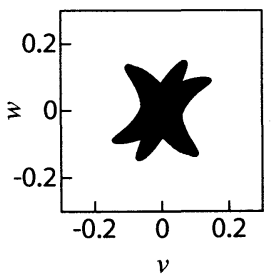

(c) $\varepsilon \sigma=0.032$
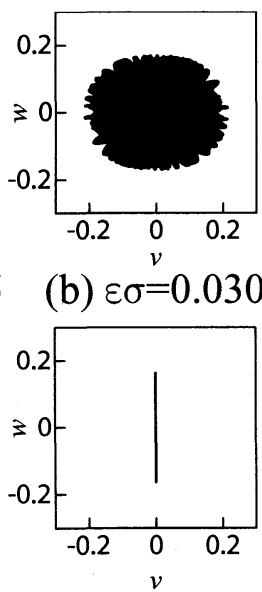

(d) $\varepsilon \sigma=0.040$ (b) $\varepsilon \sigma=0.030$

Fig. 9 Pipe motion in the $Y-Z$ plane $\left(\varepsilon_{\kappa}=0.024\right)$

るにつれて, $X-Z$ 面内の横振動のうなりは小さくな る. また卓越した二本の振動数成分の中で低い方は自 励振動の振動数, 高い方は管内脈動流の振動数の半分 $v / 2$ に対応する.

図 9 に, 図 8 の各時刻歴に対応する $Y-Z$ 面内での 管の挙動を示す. 同図 (a),(b),(c) より $\varepsilon \sigma$ が安定な定 常解が存在する境を僅かに超えた場合には，管は空間 的に複雑な挙動を示すことが分かる.

\section{5. 実験}

前報 ${ }^{(7)}$ と同様に内径 $7(\mathrm{~mm})$, 外径 $12(\mathrm{~mm})$, 全長 $518(\mathrm{~mm})$ および単位長さ当りの質量 $1.2(\mathrm{~g} / \mathrm{cm})$ のシリ コンチューブを用いて実験を行なった. 管内を流れる流 体には水を用い，管下端を弾性支持するばねには直径 0.5(mm) のピアノ線を加工したコイルばねを用いた.

実験に用いた管の曲け剛性は $E I=1.0 \times 10^{-2}\left(\mathrm{~N} \cdot \mathrm{m}^{2}\right)$ であり，管下端のばね定数は $k=0.36(\mathrm{~N} / \mathrm{m})$, 付加質 量は $M=18.0(\mathrm{~g})$ である.これらの実験值は, 4.2 節で 用いた無次元パラメータの值に対応している.

管の横変位 $v, w$ を，二台の CCD カメラによる画像 処理システムを用いて，管上端から 390(mm) の位置 に取り付けた反射テープからの反射光を利用して三次 元非接触で測定した. また電磁流量計により管内流速 $v_{f}$ を測定した．管内流速の脈動成分は，管上端に存在 するタンクの支流に取り付けた電磁弁を開閉させるこ とにより発生させた.

また $v$ を増加させた場合と減少させた場合におい て, 現象の定性的な違いは認められなかった. なおこ れ以降に示す $\varepsilon_{\kappa}$ の実測値小数点 2 桁目の添字は参考
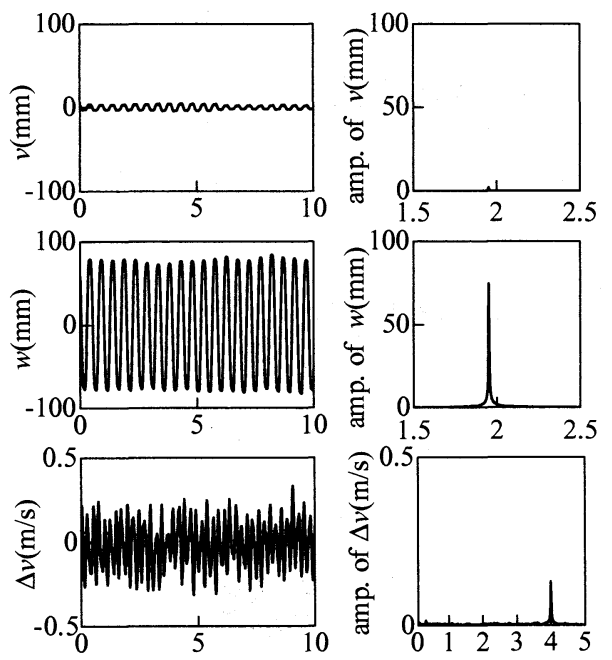

$t(\mathrm{~s})$

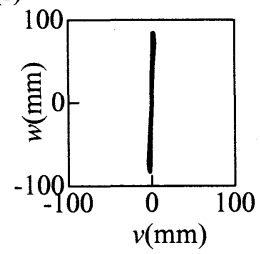

Freq. (Hz)

Fig. 10 Time histories of $v, w$ and $\Delta v(v=3.9 \mathrm{~Hz})$

值として示した.

図 11,10 に, $\varepsilon_{\kappa}=0.2_{4}$ で $v$ が 4.3,3.9(Hz) の場合に 観察された, 空間運動, 平面運動を $v, w$ および $\Delta v$ の時 刻歴と管横変位のリサージュで示す.

図 11 に示すように，うなりを伴う空間運動が観察 された.このうなりを伴う空間運動は, 図 8(b)に示し たものと同様に周期性が見受けられなかった. またそ の主要な振動数成分は, 二次の固有振動数近傍に幅を 持って存在しており, 理論解析の図 8 と定性的に一致 している.

$v$ を減少させ管の固有振動数の 2 倍近傍に近づける と, 図 10 より管は管内脈動流の振動数の $1 / 2$ 倍成分 が支配的な定常横振動をする. すなわち管の横振動は 管内脈動流による係数励振現象に引き込まれる.この とき，管は，下端支持剛性の小さい $X-Z$ 面内が支配 的な平面運動をした。

その他の代表的な $Y-Z$ 平面内での管の挙動を図 12 に示す. 同図 (a) では, 図 8(a) および (c) のように管の 横振動は二次モードの固有振動数近傍において複数の 振動数成分を有し, その軌道は $Y-Z$ 面内で広がりを 持つ. また同図 (b)より, $v$ が管の二次の固有振動数か ら離れると，管の運動は下端支持剛性の小さい $X-Z$ 

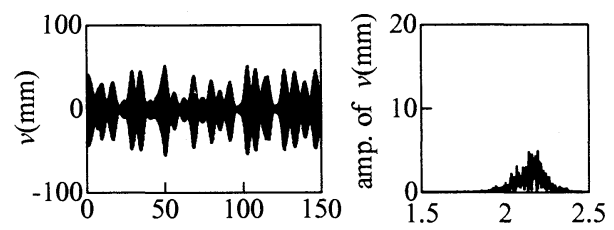

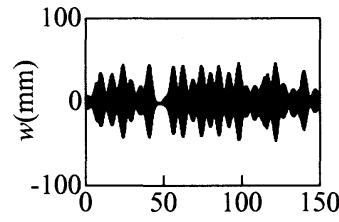

$t$ (s)
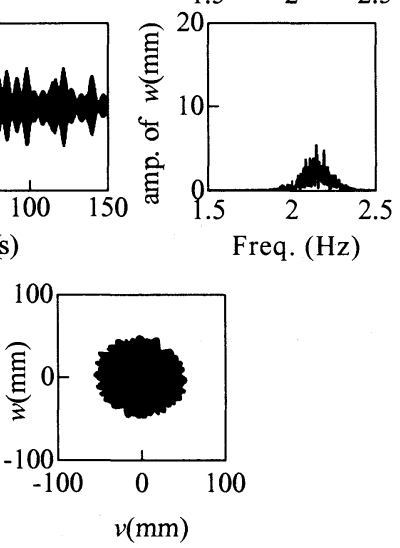

Fig. 11 Time histories of $v$ and $w(v=4.3 \mathrm{~Hz}, \varepsilon \sigma=$ 0.048)
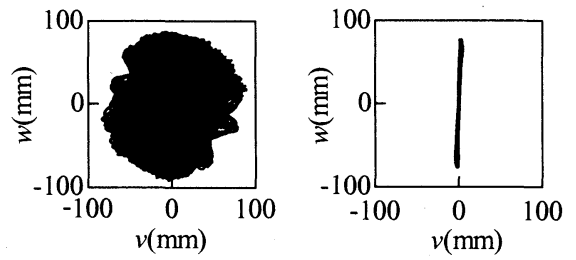

(a) $v=4.2(\mathrm{~Hz}), \varepsilon \sigma=0.024$

(b) $v=4.5(\mathrm{~Hz}), \varepsilon \sigma=0.098$

Fig. 12 Pipe motion in $Y-Z$ plane

面内が支配的な平面運動をした.

\section{6. おわりに}

本研究では管上端を固定され，管下端の付加質量を ばね支持された弾性送水管の空間的挙動を調べた。

まず管内流の脈動成分および管下端のばねの支持方 式が管内定常流速による管の自励的横振動に与える影 響について理論的に調べ，以下の結論を得た。

(1) 管下端のばね支持が対称な場合, 管の運動は初期 条件に依存して決定される平面内の定常横振動あるい はうなりを伴う横振動として現れる.とりわけ管内脈 動流成分の振動数が管の固有振動数の二倍近傍である 時，管の横振動は係数励振現象に引き込まれる.

(2) 管下端のばね支持が非対称な場合, 管内脈動流成 分の振動数が管の固有振動数の二倍近傍から僅かに遠
ざかると，管は振動振幅のうなりを伴う複雑な空間運 動をする. そして管内脈動成分の振動数を固有振動数 の二倍に近づけると，下端ばね支持が対称な場合と同 様に管の横振動は管内脈動流による係数励振現象に引 き込まれ平面運動となる.

次にシリコンチューブを用いた実験を行なうことに より以下のことが確認された.

(3) 管内脈動流成分の振動数が管の固有振動数の二倍 近傍において, 理論解析結果と定性的に一致する空間 運動を確認すると共に, 脈動流成分の半分の振動数が 支配的な定常面内横振動すなわち係数励振現象への引 き込みを明確に捉えた.

おわりに，本研究に惜しみない協力をいただいた慶 應義塾大学大学院生の新谷智史氏および廣瀬裕己氏に 感謝の意をあらわします.

\section{文献}

(1) Gregory, R.W. and Païdoussis, M.P., Unstable Oscillation of Tubular Cantilevers Conveying Fluid I. Theory, Proceedings of the Royal Society(London), Vol.293,No.1435 , (1966), pp.512-527.

(2) Païdoussis, M.P., Fluid-Structure Interactions Slender Structures and Axial Flow Volume1, (1998),242-243,Academic press.

(3) Bajaj, A.K., Nonlinear dynamics of tubes conveying a pulsatile flow, Dynamics and Stability of systems, Vol.2,No.1, (1987), 19-41.

(4) Semler, C. and Païdoussis, M.P., Nonlinear Analysis of the Parametric Resonance of a Planar FluidConveying Cantilevered Pipe, Journal of Fluids and Structures, Vol.10,No.7, (1996), pp.787-825.

(5) Yoshizawa, M. et al., Nonlinear Lateral Vibration of a Vertical Fluid-Conveying Pipe with End Mass, JSME International Journal, Series C, Vol.41,No.3, (1998), pp.652-661.

(6) Yamashita,K. et al., Beating Phenomena of a Pipe Conveying Fluid with a Spring Supported End, Transactions of the Japan Society of Mechanical Engineers, Series C, Vol.70,No.694, (2004), pp.1573-1580.

(7) Yamashita,K. et al., Nonplanar Vibration of a Pipe Conveying Fluid(In Case of an Asymmetrical Spring Supported End), Transactions of the Japan Society of Mechanical Engineers, Series C, Vol.69,No.688, (2003), pp.3141-3148. 